Modernity, Minority, and the Public Sphere 


\section{Leiden Studies in Islam and Society}

Editors

Léon Buskens (Leiden University)

Petra M. Sijpesteijn (Leiden University)

Editorial Board

Maurits Berger (Leiden University) - R. Michael Feener

(Oxford University) - Nico Kaptein (Leiden University)

Jan Michiel Otto (Leiden University) - David S. Powers (Cornell University)

VOLUME 4

The titles published in this series are listed at brill.com/lsis 


\title{
Modernity, Minority, and the Public Sphere
}

Jews and Christians in the Middle East

\author{
Edited by
}

\author{
S.R. Goldstein-Sabbah \\ H.L. Murre-van den Berg
}

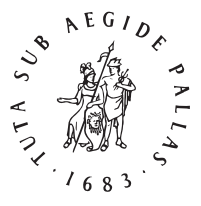

B R I L L 
We wish to thank the Nwo in particular for their support in providing the funding for language editing and making the volume available in Open Access so that our work can be shared with the larger academic community.

Cover illustration: The Funeral of King Hussein, Jerusalem, June 4, 1931, American Colony (Jerusalem). Photo Dept., photographer, LC-M32- 50380-x [P\&P], Repository: Library of Congress Prints and Photographs Division.

Library of Congress Cataloging-in-Publication Data

Names: Goldstein-Sabbah, S. R., editor | Murre-van den Berg, H. L. (Hendrika Lena), 1964- editor. Title: Modernity, minority, and the public sphere : Jews and Christians in the Middle East / edited by S.R.

Goldstein-Sabbah, H.L. Murre-van den Berg.

Other titles: Leiden studies in Islam and society ; v. 4.

Description: Leiden : Brill, 2016. | Series: Leiden studies in Islam and society; volume 4 | Includes bibliographical references and index.

Identifiers: LCCN 2016018308 (print) | LCCN 2016024319 (ebook) | ISBN 9789004322905 (pbk. : alk. paper) | ISBN 9789004323285 (E-book)

Subjects: LCSH: Religious minorities-Middle East-Congresses. | Minorities-Middle East-Congresses. | Jews-Middle East-Congresses. | Christians-Middle East-Congresses. | Muslims-Middle East-Congresses. | Middle East-Ethnic relations-Congresses.

Classification: LCC DS58 .M64 2016 (print) | LCC DS58 (ebook) | DDC 305.6/70956-dc23

LC record available at https://lccn.loc.gov/2016018308

Typeface for the Latin, Greek, and Cyrillic scripts: “Brill”. See and download: brill.com/brill-typeface.

ISSN 2210-8920

ISBN 978-90-04-32290-5 (paperback)

ISBN 978-90-04-32328-5 (e-book)

Copyright 2016 by the Editors and Authors.

This work is published by Koninklijke Brill NV. Koninklijke Brill NV incorporates the imprints Brill, Brill Hes \& De Graaf, Brill Nijhoff, Brill Rodopi and Hotei Publishing.

Koninklijke Brill NV reserves the right to protect the publication against unauthorized use and to authorize dissemination by means of offprints, legitimate photocopies, microform editions, reprints, translations, and secondary information sources, such as abstracting and indexing services including databases. Requests for commercial re-use, use of parts of the publication, and/or translations must be addressed to Koninklijke Brill NV.

This book is printed on acid-free paper and produced in a sustainable manner. 


\section{Contents}

Acknowledgements VII

List of Contributors VIII

\section{PART 1}

A Chronology of Space

1 Searching for Common Ground: Jews and Christians in the Modern

Middle East 3

H.L. Murre-van den Berg

2 The Changing Landscape of Muslim-Jewish Relations in the Modern Middle East and North Africa 39

D.J. Schroeter

\section{PART 2}

Arabic and Its Alternatives

3 Standardized Arabic as a Post-Nahḍa Common Ground: Mattai bar Paulus and His Use of Syriac, Arabic, and Garshuni 71

T.C. Baarda

4 Jewish Education in Baghdad: Communal Space vs. Public Space 96 S.R. Goldstein-Sabbah

5 Preserving the Catholics of the Holy Land or Integrating Them into the Palestine Nation (1920-1950)? 121

K.M.J. Sanchez Summerer 
PART 3

Urban Presence

6 Ottoman Damascus during the Tanzimat: The New Visibility of Religious Distinctions 155

A. Massot

$7 \quad$ The King is Dead, Long Live the King! Jewish Funerary Performances in the Iraqi Public Space 185

A. Schlaepfer

8 Jerusalem between Segregation and Integration: Reading Urban Space through the Eyes of Justice Gad Frumkin 205

Y. Wallach

\section{PART 4}

Transnationalism

9 Refugee Camps and the Spatialization of Assyrian Nationalism in Iraq 237

L. Robson

10 The League of Nations, A-Mandates and Minority Rights during the Mandate Period in Iraq (1920-1932) $\quad 258$

H. Müller-Sommerfeld

11 "Soundtracks of Jerusalem": YouTube, North African Rappers, and the Fantasies of Resistance $\quad 284$

A. Boum

Index 311 


\section{Acknowledgements}

The current volume results from a research project funded by the Netherlands Research Council (NWO): Arabic and its Alternatives: Religious Minorities in the Formative Years of the Modern Middle East (1920-1950) whose members organized a conference at Leiden University entitled Common Ground: Changing Interpretations of public space in the Middle East amongJews, Christians, and Muslims in the 19th and 2oth Century in October of 2014. The conference was organized in cooperation with the Centre for the Study of Islam and Society (LUCIS) at Leiden University, and we are grateful for their support in addition to the support of the Nwo. We wish to thank NwO in particular for their support in providing the funding for language editing and making the volume available as Open Access so that our work can be shared with the larger academic community. Also to be mentioned in our acknowledgment of thanks is Valerie Joy Turner, our tireless language editor, who endeavored to ensure linguistic coherence and consistency throughout the volume and our student assistant Farah Bazzi, who helped both in the organization of the original conference and the preparation of this volume. Finally, we want to express our gratitude to the whole team of editors at Brill for their cooperation in the preparation of this volume.

The editors 


\section{List of Contributors}

\section{Sasha Goldstein-Sabbah}

is a Ph.D. candidate at Leiden University in the Netherlands. She is a member of the Arabic and its Alternatives: Religious Minorities in the Formative Years of the Modern Middle East (1920-1950) research project funded by the Netherlands Research Council (Nwo). Her research interests focus on the history of Jews in the Arab World. Prior to her doctoral research she worked in academic publishing.

\section{Anais Massot}

is a Phd student at Leiden University and the Ecole des Hautes Etudes en Sciences Sociales (EHESs-Césor). Her Ph.D. research, for which she received a doctoral contract funded by Hesam Université (Paris Nouveaux Mondes) explores inter-confessional relations and political changes in Damascus in the late 18 th and early 19 th centuries.

\section{Hannah Müller-Sommerfeld}

is a scholar of religious studies at the Religionswissenschaftliche Institut of the University of Leipzig. She is specialized on the history and dynamics of religious minorities in the Middle East and Europe. Müller-Sommerfeld wrote her dissertation on the Romanian historian of religions Mircea Eliade. She has published (as Hannelore Müller) furthermore monographs on the modern history of Karaites (2010) and two volumes on various religious communities in the Middle East (2009, 2014). Currently, H. Müller-Sommerfeld is preparing the publication of her post-doctoral research about religion, international politics and law during the monarchy in Iraq.

\section{Heleen Murre-van den Berg}

received her Ph.D. from Leiden University in 1995 and is currently director of the Institute of Eastern Christian Studies at Radboud University, Nijmegen since June 2015. Earlier, she taught history of World Christianity at Leiden University. She has published extensively on Christianity in the Middle East, especially on the Syriac/Assyrian traditions and the interactions between Western and Middle Eastern Christians in the period from 1500 onwards. The current volume results from a research project funded for by the Netherlands Research Council (NWO): Arabic and its Alternatives: Religious Minorities in the Formative Years of the Modern Middle East (1920-1950). 


\section{Laura Robson}

received her Ph.D. from Yale University and is currently Associate Professor of modern Middle Eastern history at Portland State University in Portland, Oregon. Her research focuses primarily on histories of ethnic and religious minorities in the twentieth century Arab world. She is the author of Colonialism and Christianity in Mandate Palestine (University of Texas Press, 2011) and editor of Minorities and the Modern Arab World: New Perspectives (Syracuse University Press, 2016). Her articles have appeared in a number of scholarly journals, including the Journal of Palestine Studies, Comparative Studies of South Asia Africa and the Middle East, the Journal of Imperial and Commonwealth History, First World War Studies, History Compass, and Mashriq and Mahjar. She is currently working on a book investigating the history of ethnically based population transfers and partitions across Iraq, Syria, and Palestine during the interwar period.

\section{Aline Schlaepfer}

holds a Ph.D. in Middle Eastern Studies from the University of Geneva. She was a visiting research student at the School of Oriental and African Studies in London, and a lecturer at the University of Geneva. She was awarded a postdoctoral fellowship by the Swiss National Science Foundation and is now a research affiliate at the American University of Beirut (CAMES), where she currently lives. Her research interest focuses on modern Arab intellectual history, history of Arab nationalism and the history of Jews in Arab lands. She is the author of Les intellectuels juifs de Bagdad. Discours et allégeances (1908-1951), Leiden, Brill, 2016.

\section{Daniel J. Schroeter}

is the Amos S. Deinard Memorial Chair in Jewish History at the University of Minnesota. His works include The Sultan's Jew: Morocco and the Sephardi World (Stanford University Press, 2002), and Merchants of Essaouira: Urban Society and Imperialism in Southwestern Morocco, 1844-1886 (Cambridge University Press, 1988); both books were translated to Arabic and published in Morocco. He co-edited with Emily Gottreich, Jewish Culture and Society in North Africa (Indiana University Press, 2011), and is an editor and contributor to the Encyclopedia of the Jews in the Islamic World (Brill, 2010). He was the 2014-2015 Ina Levine Scholar-in-Residence at the Jack, Joseph and Morton Mandel Center for Advanced Holocaust Studies of the United States Holocaust Memorial Museum, and is working on a book with Aomar Boum on Morocco and the Holocaust. 


\section{Karène Sanchez Summerer}

is Assistant Professor at Leiden University. Her research considers the European linguistic and cultural policies in Palestine (1860-1948), with a focus on French heritage in a comparative perspective; the educative and sanitary Catholic and Anglican missions in Ottoman and British Mandate Palestine. She is currently working on two research projects: the role of language and education among the Palestinian Catholic communities (The Netherlands National Research Agency Nwo project 'Arabic and its alternatives. Religion and Language Change in the Formative Years of the Modern Middle East (1920-1950)', 2012-2017); and the engagement of Christian missions in Humanitarianism in the Middle East (Nwo project 'Engaging Europe in the Arab World: European missionaries and humanitarianism in the Middle East; 1850-1970', 2015-2018).

\section{Tijmen Baarda}

started in October 2012 a Ph.D. programme within the Nwo project 'Arabic and its Alternatives' led by Professor Heleen Murre-van den Berg. His research concerns the intellectual endeavours of the Syriac Christians of Iraq in the period 1920-1950, including their publications and educational activities, with a special focus on the many different languages they used. In his Ph.D. thesis, he aims to answer the question how the diverse group of Syriac Christians of Iraq positioned themselves towards the Iraqi state and society and other Christians in the Middle East, by using and teaching Arabic, Syriac, Neo-Aramaic and other languages, and how they responded to and took part in phenomena such as Arab and Assyrian nationalism.

\section{Aomar Boum}

is an Associate Professor of sociocultural anthropology at the University of California, Los Angeles, and faculty fellow at the Université Internationale de Rabat, Morocco. A native of M'Hamid oasis of southern Morocco, Boum has a varied research focus that revolves around ethnic and religious minorities, Islam, anthropology of religion, youth, festival, historiography, and sociology of Morocco, North Africa, sub-Saharan Africa, and the Middle East. He is coauthor of the 2006 and 2016 editions of the Historical Dictionary of Morocco and A Concise History of the Middle East (2015). He has also published many articles on Morocco and religious minorities, as well as the book Memories of Absence: How Muslims Remember Jews in Morocco (2013). Currently he is finishing a book manuscript with Daniel Schroeter on the monarchy and Holocaust politics in Morocco. 


\section{Yair Wallach}

is a Lecturer in Israeli Studies at the department of Near and Middle Eastern Languages and Cultures, sOAs, University of London. His interests are in urban and visual culture in modern Israel/Palestine from the late Ottoman period to the present day. Before joining soAs he was a research associate in the project "Conflict in Cities" at the University of Cambridge. He has written on the use of maps as visual symbols in Israeli and Palestinian nationalism, Muslim-Jewish acculturation, and on urban texts (signs, graffiti and banners) in the public sphere of modern Jerusalem. 